\title{
ПРОБЛЕМИ ЗДІЙСНЕННЯ ТУРИСТИЧНОЇ ДІЯЛЬНОСТІ В УМОВАХ КАРАНТИНУ
}

Анотація. У статті встановлено теоретичні аспекти щодо суб'єктів туристичної діяльності та досліджено форми державного контролю за цими суб’ектами. Серед таких форм - ліцензування, видання дозволів та присвоєння категорій, без яких суб'єкти туристичної діяльності не мають права здійснювати свої повноваження. Основний акцент зроблено на виявленні та кваліфікації порушень прав туристів. Автори статті допускають, що загальна причина непоодиноких випадків порушень прав споживачів туристичних послуг полягає в поганій правовій освіченості громадян і їхньому небажанні відстоювати свої порушені права. Зазначено основні випадки порушень. Досліджено проблему порушень прав споживачів туристичних послуг у рамках карантину. На підставі аналізу судової практики, виявлено, які ситуації порушень є найбільш частими в зазначених умовах. Запропоновано шляхи вирішення наведених у статті проблем.

Ключові слова: туристична діяльність, права туристів, порушення прав туристів, туризм в умовах карантину, права споживачів.

Pentilo Daria, Orel Lilia

Borys Grinchenko Kyiv University

\section{PROBLEMS OF TOURIST ACTIVITY IN QUARANTINE CONDITIONS}

Summary. The article establishes the theoretical aspects of the subjects of tourist activity, which include tour operators; travel agents; other business entities that provide accommodation, catering, excursion, entertainment services; tourist support specialists, etc. Forms of state control over these entities have been studied. Such forms include licensing, issuing permits and assigning categories without which tourism entities do not have the right to exercise their powers. The main emphasis is on identifying and qualifying violations of tourists' rights. The main cases of violations are indicated: failure of the tour operator or travel agent to provide information on additional costs for temporary accommodation services, providing the tour operator or travel agent with inaccurate information on living conditions in the temporary accommodation, entry and exit conditions to / from the visited country, change contract prices after its conclusion for reasons that are not valid. The authors of the article assume that the common cause of many cases of violations of the rights of consumers of tourist services is poor legal education of citizens and their unwillingness to defend their violated rights. The problem of violations of the rights of consumers of tourist services under quarantine has been studied. In 2020-2021, more than ten cases of termination of contracts for the provision of tourist services and claiming material and / or moral compensation, which occurred as a result of the spread of acute respiratory disease COVID-19, were resolved in Ukrainian courts. Based on the analysis of case law, it is revealed which situations of violations are the most frequent in these conditions. The article provides a detailed example of a lawsuit against a tour operator for the return of funds due to contractual relations that have not entered into force due to a force majeure quarantine situation. The example is supported by the arguments of the court, which allows us to understand the essence of the violation and its legal qualification. Theoretical aspects, classification of responsibility in the field of violation of the rights of consumers of tourist services are established. During the study, the authors identified a number of problems and suggested optimal ways to solve them.

Keywords: tourist activity, tourists rights, violation of tourists rights, tourism in quarantine, consumer rights.

$\Pi^{2}$ остановка проблеми. Українці все частіше стали виїжджати за кордон і, відповідно, частіше користуватися послугами туристичних операторів. Маючи на меті матеріальну наживу, суб,єкти надання туристичних послуг часто ігнорують права споживачів або навмисно створюють обставини для їх порушення. Це призводить до непоодиноких випадків звернення туристів до суду за відновленням порушених прав. Але й до суду, на жаль, звертаються не всі. Деякі не знають яким чином захистити себе, чому виною є низький рівень правової освіченості. Враховуючи такі численні випадки порушень прав туристів як споживачів туристичних послуг, існує потреба пошуку причин та шляхів мінімізації цих випадків.

Аналіз останніх досліджень і публікацій. Проблеми правового регулювання туристичної індустрії та порушень прав туристів вже досліджувалися та аналізувалася такими науковця- ми, як В.В. Александров, В.І. Биркович, I.В. Валентюк, С. Галасюк, В. Герасименко, В.І. Гостюк, M.M. Гудима, В.Ф. Кифяк, О.О. Любіцева, О.А. Мельниченко, Н.В. Сирик, В.О. Шведун, P.I. Яворський та ін. Їхні праці дали підгрунтя для орієнтування в теоретичних аспектах туристичної сорери.

Виділення не вирішених раніше частин загальної проблеми. У статті враховано такий вагомий чинник впливу сучасності, як карантин. Цей феномен наніс сильний удар по туристичному бізнесу. На жаль, відбуваються такі неприємні випадки щодо туристів-українщів, як, наприклад, не інформування, дезінформація або неповне інфрормування суб'єктами туристичної діяльності про те, що карантинні вимоги країни відвідування передбачають наявність свіжого ПЛР-тесту. Це далеко не поодинокий випадок. Ситуацій порушень прав туристів, на жаль, дуже багато. В 2020-2021 pp. більшість 3 таких ситуащй містять карантинний

${ }^{1}$ ORCID: https://orcid.org/0000-0002-7054-3751 
аспект. Ми не могли оминути цю проблему і вирішили внести ії в наше дослідження.

Мета статті. Головною метою ціеї роботи $\epsilon$ визначення основних спорів у області порушення прав споживачів туристичних послуг з урахуванням карантинного аспекту, виявлення кваліфрікації порушень та основних шляхів вирішення таких спорів.

Виклад основного матеріалу. Туризм - це пріоритетний напрям розвитку економіки та культури. Так стверджує основоположний нормативно-правовий акт регулювання туристичної сорери - Закон України «Про туризм» [1]. Пріоритетність і актуальність такого напряму як туризм відображається і на кількості відкритих підприємств. Згідно з українським Ліцензійним реєстром суб'єктів туроператорської діяльності, станом на 12 грудня 2019 року 2792 юридичні особи зареестрували себе як суб'екти туроператорської діяльності і отримали ліцензію [2]. Такий високий показник свідчить про попит споживачів, адже все ще діє відоме маркетингове правило «попит породжуе пропозицію». Там, де є попит, найчастіше за все, присутній високий інтерес надавача послуг. Саме цей фрактор в сумі 3 менталітетом наших громадян та їхньою правовою неосвіченістю призводить до численних порушень прав споживачів туристичних послуг.

У 2020 році весь світ підпав під карантинні обмеження. Цей феномен глобально змінив сталі формати роботи у багатьох сфрерах життя, в тому числі у підприемництві. Туризм під впливом карантину зазнав великих втрат і ударів по прибуткам. Відповідно, під страхом втратити перспективи прибутку, суб'єкти туристичної діяльності вдаються до різноманітних методів приваблення клієнтів і не дивно, що деякі з таких методів порушують права тих самих клієнтів.

Процес споживання туристичних послуг є специфічним у порівнянні зі стандартним розумінням форм споживання. Він несе комплексний характер, оскільки споживач зацікавлений мульти-результатом у вигляді враження від відпочинку, задоволення, оздоровлення та матеріальних придбань. А от надавач туристичних послуг в єдиному результаті у вигляді прибутку [3].

Що стосуеться прав споживачів у сфрері туристичних послуг, відмінностей від інших сдер немає. Оскільки статус споживача у цих відносинах зберігається, а тому такі відносини регулюються Цивільним кодексом, Законом України «Про захист прав споживачів» та іншими нормативно-правовими актами у сфрері прав споживачів, з урахуванням нюансів туристичних послуг.

Основні шляхи державної політики у сорері туризму і кроки створення умов для туристичної діяльності визначає Закон України «Про туризм». Стаття 1 цього Закону встановлюе, що туризм - тимчасовий виїзд особи з місця проживання в оздоровчих, пізнавальних, професійноділових чи інших цілях без здійснення оплачуваної діяльності в місці, куди особа від'їжджає [1].

Досліджуючи питання порушення прав туристів 3 урахуванням карантинного аспекту, варто спочатку розібратися з тим, хто і на підставі чого має право на здійснення туристичної діяльності. Законодавчою базою визначено, що суб'єктами туристичної діяльності є:
- туристичні оператори (туроператори);

- туристичні агенти (турагенти);

- інші суб'єкти підприємницької діяльності, що надають послуги 3 тимчасового розміщення (проживання), харчування, екскурсійних, розважальних та інших туристичних послуг;

- гіди-перекладачі, екскурсоводи, спортивні інструктори, провідники та інші фрахівці туристичного супроводу;

- фрізичні особи, які не є суб'єктами підприемницької діяльності, що надають послуги з тимчасового розміщення (проживання), харчування тощо [1, ст. 5].

Тобто, національна нормативно-правова база виділяе нам п'ять видів суб'єктів туристичної діяльності. Однак, оскільки туристична діяльність відповідно до Господарського кодексу України підпадає під ознаки самостійної, ініціативної, систематичної діяльності по наданню послуг, що здійснюеться фрізичними та юридичними особами, зареєстрованими як суб'єкти підприємницької діяльності, на власний ризик господарська діяльність, що здійснюеться суб'єктами господарювання 3 метою досягнення економічних і соціальних результатів та одержання прибутку, то така діяльність є підприемництвом [4, ст. 42]. Але суб'єкт підприемницької діяльності не може діяти непідконтрольно державі. Згідно Закону України «Про ліцензування певних видів господарської діяльності» туроператорська та турагентська діяльність є видом господарської діяльності, що підлягає ліцензуванню [5].

Що стосується об'єктів туристичної індрраструктури, а саме готелів, інших об'єктів, призначених для надання послуг 3 розміщення, закладів харчування, курортних закладів, то їм в обов'язковому порядку присвоюються категорії якості та рівня обслуговування, що підтверджуеться свідоцтвом. За відсутності такого свідоцтва об’єктам туристичної інфраструктури забороняеться надавати послуги [1, ст. 19].

Туристичну діяльність можуть забезпечувати і фрізичні особи, які не є суб'єктами підприємницької діяльності, що не позбавляе їх державного контролю. Фізичні особи, що здійснюють діяльність, пов'язану з туристичним супроводом, а саме гідів-перекладачів, екскурсоводів, спортивних інструкторів, провідників тощо, можуть надавати такі послуги за наявності дозволу на право здійснення туристичного супроводу, що є офріційним документом, який підтверджує кваліфрікацію фрахівця туристичного супроводу. Така норма та безпосередньо порядок отримання дозволів на право здійснення туристичного супроводу фрахівцями туристичного супроводу визначений Наказом Держтурадміністрації України від 24.09.2004 р. № 83 "Про затвердження Положення про порядок видачі дозволів на право здійснення туристичного супроводу фрахівцям туристичного супроводу" [6].

Отже, діяльність суб'єктів надання туристичних послуг підконтрольна державі і здійснюеться при наявності необхідних дозвільних документів. Проте форма дозвільних документів для провадження туристичної діяльності фрізичними особами, які не є суб'єктами підприємницької діяльності, що надають послуги з тимчасового розміщення (проживання), харчування тощо, для нас залиши- 
лася невідомою і моніторинг нормативно-правової бази не дав результатів у цьому питанні.

Жодна ліцензія, категорія чи дозвіл, на жаль, не захищають споживачів туристичних послуг. Доволі частими випадками у практиці туристів, про що нам дала змогу зробити висновок судова практика, є порушення ст. 20 Закону України «Про туризм», а саме порушення умов договору на туристичне обслуговування [1]. Зокрема, до таких випадків входять: не надання туроператором або турагентом інформації щодо додаткових витрат на послуги 3 тимчасового проживання, надання туроператором або турагентом недостовірної інформації щодо умов проживання у об'єкті тимчасового проживання, щодо умов в їзду та виїзду до/з відвідуваної країни (зокрема це стосується випадків про карантинні обмеження та вимоги, пов'язані з такими обмеженнями), зміна ціни договору після його укладення з причин, що не відносяться до поважних, відповідно до закону тощо.

Законодавство передбачає повну відповідальність туроператора або турагента за порушення умов договору, його неналежне виконання або невиконання і встановлює вичерпний список ситуацій, коли суб'єкт туроператорської діяльності не несе відповідальності. До них відносяться:

- невиконання або неналежне виконання умов договору, що сталося з вини туриста;

- невиконання або неналежне виконання умов договору на туристичне обслуговування, що сталося з вини третіх осіб, не пов'язаних з наданням послуг, зазначених у цьому договорі, та жодна із сторін про їх настання не знала і не могла знати заздалегідь;

- невиконання або неналежне виконання умов договору на туристичне обслуговування, що сталося внаслідок настання фрорс-мажорних обставин або $є$ результатом подій, які туроператор (турагент) та інші суб'єкти туристичної діяльності, які надають туристичні послуги, включені до туристичного продукту, не могли передбачити [1].

Аналіз судової практики щодо питання договорів на туристичне обслуговування під час пандемії дав змогу окреслити проблему, що найчастіше зустрічалася в описаних умовах. На прикладі рішення Дніпровського районного суду м. Киева від 23.12.2020 p. по справі № 755/10977/20, ми хочемо встановити певні закономірності у цьому питанні. Причиною судового провадження по зазначеній ситуації став типовий спір в аспекті численних ситуащій у сфері туризму, спричинених гострою респіраторною хворобою COVID-19, а саме спір про пред'явлення вимоги про повернення коштів позивачем до туроператора з причини договірних відносин, що не вступили в силу, у зв'язку з форс-мажорною ситуащією карантину. Позивач зазначив, що туристичні послуги надані не були з вищевказаних підстав та зобов язання за укладеним договором припинилось за неможливістю їх виконання.

Туроператор або турагент зобов'язаний не пізніш як через один день 3 дня, коли йому стало відомо про зміну істотних обставин, та не пізніш як за три дні до початку туристичної подорожі повідомити туриста про таку зміну, щоб останній міг відмовитися від виконання договору або внести зміни до нього. Проте такого не відбулося і по- зивач сам виніс пропозищію повернути кошти, на що відповіді не отримав. Це і підштовхнуло до витребування коштів у судовому порядку.

Суд акцентує, що відповідач в порушення вимог ст. 20 Закону України «Про туризм» з метою продовження туристичного обслуговування відповідно до договору не вжив альтернативних заходів без покладення додаткових витрат на позивача, який не порушив його умов. У висновку, суд задовольнив позовні вимоги у повному обсязі [7].

Судова практика має більше десяти схожих випадків. Але ж далеко не всі громадяни звертаються за захистом до суду, більшість взагалі не прагне до відновлення своїх порушених прав. Тому судова практика поки не містить рішень по ситуаціям не повного інформування або дезінформація туроператорами споживачів туристичних послуг з приводу карантинних вимог у країнах відвідування. Адже трапляються випадки, коли суб'єкти надання туристичних послуг, не повідомляють про те, що карантинні вимоги країни відвідування передбачають наявність свіжого ПЛР-тесту. Це призводить до відмов у перевезенні туристів і ставить їх в скрутне становище.

За таке та інші порушення прав туристів як споживачів туристичних послуг відповідальність встановлюеться законодавством України, зокрема ст. 23 Закону України «Про захист прав споживачів» [8].

Класифікуючи цивільну відповідальність суб'єктів туристичної діяльності за ознакою видів договорів, що укладаються у сфрері туристичної діяльності, можемо отримати три групи:

- туроператора або турагента перед туристом; - туроператора або турагента перед партнерами;

- туриста, об'єднання туристів перед туроператором або турагентом.

Майнову відповідальність несе суб'єкт туристичної діяльності, який порушив законодавство у галузі туристичної діяльності при наданні туристичної послуги, тобто порушив умови договору між туристом і суб'єктом туристичної діяльності з надання туристичних послуг, та за вини якого замовнику завдано збитків.

Однак, у науковій доктрині ще існуе поділ на два «блоки» відповідальності за іншою ознакою. Перший блок компенсаційний, другий - штрафрний. Це пояснюеться видами санкцій, що можуть застосовуватися за порушення прав споживачів туристичних послуг, а саме встановленими розмірами компенсацій вартості відповідних послуг та встановленими розмірами штрафів у відповідних випадках. Компенсація шкоди, заподіяної життю чи здоров'ю туриста або його майну, провадиться у порядку, передбаченому чинним законодавством України [9].

Висновки і пропозиції. Отже, туристичні послуги можуть надавати:

- туроператори та турагенти при наявності ліцензій, отриманих у встановленому порядку;

- фрахівці туристичного супроводу при наявності дозволів, отриманих у встановленому порядку;

- об'єкти туристичної інфрраструктури - при присвоєнні їм відповідних категорій, типів та класів і дотриманні встановленого рівня обслуговування.

Проте, щодо форми дозвільних документів для провадження туристичної діяльності фpi- 
зичними особами, які не є суб'єктами підприємницької діяльності, що надають послуги 3 тимчасового розміщення (проживання), харчування тощо, питання для нас є відкритим. Тому, на нашу думку, Закон України «Про туризм» потребуе систематизації в питанні дозвільних документів для кожного виду суб'єктів туристичної діяльності. Адже зазначений закон має статті, що встановлюють норми про ліцензії та про категорії (для туристичної інфраструктури), але не містить жодних вказівок на дозвільні документи для інших видів суб'єктів.

Законодавство у сфрері туризму не можна назвати скупим на санкції щодо порушення прав споживачів туристичних послуг. Однак, карантинний аспект не врахований у нормах про туризм та права туристів. Незважаючи на це, основний корінь проблеми в тому, що туристиспоживачі часто не розуміють, що можуть відстояти своє право, бояться або не хочуть цього робити. Також не варто забувати про те, що в незвичних для нас умовах, під час пандемії, дуже легко вводити споживачів в оману і користуватися тим положенням, що всі люди на такому переломному моменті більш вразливі і довірливі. Для покращення ситуації ми пропонуємо ввести певні зміни:

- посилення санкцій за порушення прав споживачів;

- введення законодавчої умови, щодо обов'язкового ознайомлення споживачів туристичних послуг з карантинними вимогами нашої країни та країни відвідування на період карантину через гостру респіраторну хворобу COVID-19;

- законодавче винесення вимоги про обов'язкове інформування в письмовій фрормі споживачів туристичних послуг про відповідальність туроператора або турагента, у разі невиконання або неналежного виконання договору та можливі шляхи захисту своїх прав.

На нашу думку, виправлення зазначених недоліків змінить ситуацію, що складається в туристичній сфері на краще і допоможе підтримувати статус туристичної сфрери як пріоритетної.

\section{Список літератури:}

1. Про туризм : Закон України від 15.09.1995 р. № 324/95-ВР. Відомості Верховної Ради України (ВВР), 1995 , № 31, ст. 24 .

2. Ліцензійний реєстр суб’єктів туроператорської діяльності. Єдиний державний веб-портал відкритих даних. URL: https://data.gov.ua/dataset/b0b0b691-eb79-46d5-b902-1c9fad26ad85

3. Любіцева O. О. Ринок туристичних послуг. URL: http://tourlib.net/books_ukr/lubiceva_rtp43.htm

4. Господарський кодекс : Кодекс від 16.01.2003 p. № 436-IV. URL: https://zakon.rada.gov.ua/laws/show/436-15\#Text

5. Про ліцензування певних видів господарської діяльності : Закон України від 02.03.2015 p. № 222-VIII. Відомості Верховної Ради України (ВВР), 2015, № 23, стор. 1234, ст. 158.

6. Про затвердження Положення про порядок видачі дозволів на право здійснення туристичного супроводу фрахівцям туристичного супроводу : Наказ Державної туристичної адміністрації України від 24.09.2004 p. № 83. Офіційний вісник України, 2004, № 42, стор. 326, ст. 2812, код акта 30454/2004.

7. Рішення Дніпровського районного суду м. Киева по справі № 755/10977/20 від 23 грудня 2020 р. URL: https://reyestr.court.gov.ua/Review/93802965

8. Про захист прав споживачів : Закон України від 12 травня 1991 року № 1023-ХІІ. Відомості Верховної Ради УРСР (ВВР), 1991, № 30, ст. 379.

9. Сирик Н. В. Договор оказания туристских услуг. URL: http://library.shu.ru/pdf/sirik01.pdf

\section{References:}

1. Law of Ukraine on tourism № 324/95 (1995.09.15). Vidomosti Verhovnoyi Rady Ukrayiny, 31, 24. (in Ukrainian)

2. Licensed register of tour operators. Yedynyi derjavnyi veb-portal vidkrytyh danyh. URL: https://data.gov.ua/ dataset/b0b0b691-eb79-46d5-b902-1c9fad26ad85 (in Ukrainian)

3. Liubitseva O.O. Travel services market. URL: http://tourlib.net/books_ukr/lubiceva_rtp43.htm (in Ukrainian)

4. Commercial Code Ukraine (2003.01.16) № 436-IV URL: https://zakon.rada.gov.ua/laws/show/436-15\#Text (in Ukrainian)

5. Law of Ukraine on licensing of certain types of economic activity № 222-VIII (2015.02.03). Vidomosti Verhovnoyi Rady Ukrayiny, 23, 158. (in Ukrainian)

6. Order of the State Tourist Administration of Ukraine on approval of the Regulations on the procedure for issuing permits for the right to provide tourist support to specialists in tourist support №83 (2004.09.24). Oficiynyi Visnyk Ukrayiny, 42, 2812. (in Ukrainian)

7. Decision of the Dniprovsky District Court of Kyiv in the case № 755/10977/20 (2020, December, 23). URL: https://reyestr.court.gov.ua/Review/93802965 (in Ukrainian)

8. Law of Ukraine on Consumer Protection № 1023-XII (1991.05.12). Vidomosti Verhovnoyi Rady, 30 , 379. (in Ukrainian)

9. Syryk N. Contract for the provisionof tourist services. URL: http://library.shu.ru/pdf/sirik01.pdf 